\title{
Critiquing and Analyzing the Effects of Neoliberalism on Community Organizing: Implications and Recommendations for Practitioners and Educators
}

\author{
Shane R. Brady \\ University of Oklahoma \\ Andrew C. Schoeneman and Jason Sawyer \\ Virginia Commonwealth University
}

\begin{abstract}
Although community organizing has historic and current roots as a mode of practice, characterized by people coming together to collectively address unmet needs and/or challenge inequality, neoliberal trends beginning to form in the 1980s have negatively impacted community organizing. Neoliberal values, which promote individualism, capitalism, the existence of welfare states, and reform from solely within the system are concerning to the future of community practice. This article provides a critique and analysis of the impact of neoliberalism on community organizing in three areas: The influence of evidence-based practice on dictating how community organizers practice, a lack of focus on social movements in community organizing, and the professionalization of community organizing, which marginalizes nonprofessionals engaged in community organizing. This article exposes potential problems arising from within community organizing as a result of neoliberalism. In order to uncover and analyze the major effects of neoliberalism, we propose a theoretical framework that combines critical theory and Foucault's work on social control. We end the analysis by providing recommendations for practitioners of community organizing as well as for educators teaching about community organizing.
\end{abstract}

\section{Problem Discussion}

This paper is written from our experience, as emerging social work scholars and seasoned community organizers, and is situated in the concept of critical community practice as it is envisioned from within the profession of social work and the practice of community organizing. Critical community practice in this article implies a preferred mode of community practice that seeks to not only reform, but also to transform unjust systems that arise from inequalities perpetuated by dominant groups (Mullaly, 2007). Critical community practice begins from a standpoint of conflict and strives to promote social justice and social change through critical praxis and social action (Butcher, Banks, Henderson, \& Robertson, 2007). In some places, other 
disciplines, e.g. community psychology, human services, and the non-profit sector, are referenced as a reminder that while social work is what we know best, there are certainly similarities with other academic perspectives around issues discussed. Still, we leave it mostly to the reader to extend and transfer the lessons drawn from this examination, grounded in a social work perspective, of the intersection of community organizing and neoliberalism. We also note that while the focus of this article is on the state of community organizing practice, it is clear that practice is unavoidably linked to education. It is impossible, in other words, to examine the impact of neoliberalism on community organizing practice without considering the ways in which higher education contributes to and is impacted by community organizing practice. Finally, we are community organizers and academics from the U.S. and as a result our lens is biased by our experiences of community organizing in the U.S.; however, we attempt to draw from existing literature about community organizing internationally, especially within the context of the global south in order to extend our discussion and inspire thinking beyond the borders of the U.S. and global north.

Community organizing, as a means of bringing together community members for the purpose of creating small and large-scale changes, is as old of a concept as community itself; however, it was the settlement house era of the late $19^{\text {th }}$ and early $20^{\text {th }}$ centuries that provides some of the first discussion of community organizing as professional practice (Addams, 1910, 1930; Garvin \& Cox, 2001). Over time, community organizing became a major modality for change in the organized labor, feminist, Native American, Chicano, civil rights, gay rights, global justice, and environmentalist movements (Garvin \& Cox, 2001; Gamble \& Weil, 2010; Reisch, 2005).

While much of the professional literature of community organizing has spawned from reform efforts in the U.S., Canada, and Europe, community organizing as a mechanism for creating people-driven change also has importance in the global south (Healy, 2001; Lyons, 2006; Tilly, 1978). One need not look any further than at recent reform efforts around same sex marriage and economic inequality in the U.S., as well as in the current social movements in Egypt and Syria to fully understand the importance of community organizing both locally and globally.

Social change is often times an ambiguous and vague term in the literature of community organizing. For the purpose of this article, social change is used in the context of community practice and refers to reforms and transformative changes attained at a community, societal, and/or global level, as a result of collective people-driven change (Harper \& Leicht, 2010). Despite the importance and impact of community organizing for persons and groups seeking to meet unmet needs and change systems, neoliberal trends in social work and community practice have altered the context and practice of community organizing in ways that raise concern for professional and nonprofessional organizers alike (Brady, 2012; Fisher \& Shragge, 2000).

Although no uniform definition for neoliberalism exists, many scholars agree that it represents underlying values that support and maintain the status quo, promotes individualism, market fundamentalism, and privatization (Hasenfeld \& Garrow, 2012; Midgley, 2001; Mullaly, 2007; Ritzer, 2008). While neoliberalism provides stability and support to societal systems, it also promotes economic inequality, dependency, and individualistic values; all of which can be restricting to community organizing and social change (Choudry \& Shragge, 2011; Pyles, 2010). Neoliberalism in community practice arose in the early 1980 s out of the need for community 
organizers to repackage community organizing as something more conservative in order to gain government funding and support (Defilippis \& Saegert, 2012; Reisch, 2005).

Until the early 1980s much of the reputation of community organizing was linked to the social action, protests, and civil disobedience emphasized in the civil rights, women's, and organized labor movements (Brady, 2012; Garvin, 2001; Wagner, 1990). From the 1980s onward, however, community organizing was repackaged and promoted as expert driven processes designed to work within the current system and labeled as community organization and/or community development (Choudry \& Shragge, 2011; Defilippis \& Saegert, 2012). Whereas the focus of community organizing in the 1960 s and 70 s was on systematic reforms and transformation, social movements, and building collective power, the organizing of the 1980s onward has emphasized collaboration, capacity building, social planning, and working within the system (Fisher \& Shragge, 2000; Rothman, Erlich, \& Tropman, 2001). The shift of community organizing away from more critical and radical practice to more conservative approaches has led to federally funded initiatives, such as Community Development Corporations (CDCs), community collaborative groups, and tax incentive programs for small businesses (Defilippis \& Saegert, 2012). While we do not discount the importance of collaboration, funding, and outcomes in community organizing, we believe that neoliberalism has led to negative consequences that have gone without adequate discussion and critique.

Although neoliberalism is often associated with U.S. economic and political values, its effects have been experienced and illustrated globally as well. One of the major flaws of neoliberalism is that it promotes dependency on government for support, while discouraging people from challenging the unjust system(s) leading to their dependency (Mullaly, 2007). In the U.S. and Canada, large portions of the population receive some form of social welfare in order to survive. For example, people in the U.S. meeting the low income or poverty criteria receive government support for food, housing, healthcare, and other related needs. While individuals considered low-income receive some help, the support is only enough to sustain them at a bare minimum standard without allowing them to attain the education, training, or other resources necessary for true upward mobility in society (Mullaly, 2007; Piven \& Cloward, 1977).

While the negative effects of neoliberalism are discussed in the literature of political science, sociology, community psychology, and social work, little focus has been paid to understanding the impact of neoliberalism on community organizing. What has been written usually focuses on the problems created by neoliberalism, but without much discussion of solutions or alternatives to neoliberalism in community organizing. This paper combines elements of critical theory with ideas promoted by the postmodern interpretive theorist Michel Foucault in order to analyze how neoliberalism is negatively impacting community organizing. Additionally, this paper will utilize the problem analysis on neoliberalism as a mechanism to provide practitioners, educators, and allies in community organizing with some tools for combating the effects of neoliberalism as well as alternatives to the neoliberal status quo.

We identify three major trends through which neoliberalism has negatively impacted community organizing practice: the promotion of evidence-based practice (EBP) as the dominant process for guiding professional community practice; the decreased attention and misrepresentation of social movements within the context of community organizing literature and education; and the increasing professionalization of community organizing. The purpose of this paper is to provide a theoretically grounded critique of the effects of neoliberalism on community organizing; 
however, we also reference its impact on the education of community organizers, as the two are difficult to separate. Lastly, we utilize the implications that are identified to provide recommendations for practitioners, researchers, and educators of community organizing.

\section{Review of the Literature}

Community organizing has early roots in the settlement house movements and the pragmatic organizing of Saul Alinsky (Garvin \& Cox, 2001). Strategies from these contributing branches of community organizing promoted participation and social action among local peoples (Gamble \& Weil, 2010). Community organizing efforts utilized consciousness raising, community building, and social action to promote empowered communities, and individual and systemic social change (Brady, 2012; Garvin \& Cox, 2001; Morris, 1984). Although community organizing has a proven track record for contributing to social change, a societal shift from more liberal values and politics to a state of neoliberalism has impacted how community organizing and social change are conceptualized and demonstrated in practice (Mullaly, 2007).

Paradigms in community organizing and academic literature are defined differently from author to author (Burrell \& Morgan, 1979; Guba, 1990; Fay, 1996; Thomas, O'Connor, \& Netting, 2011). Paradigms for the purpose of this paper are conceptualized as the underlying values associated with the knowledge base of community organizing. Paradigms provide guidance as to how knowledge is constructed, either objectively or subjectively, and whether social change occurs incrementally or radically (Guba, 1990). These underlying assumptions have always been present in community organizing. Three major forms of community practice have surfaced over the decades since the settlement house era. The three major paradigms of community practice are: 1) traditional community practice, which is defined by rationalistic methods of practice grounded in positivism and carried out using strategies and interventions derived from the scientific method; 2) collaborative practice, which is characterized by shared responsibility, collective decision making, consensus, and small scale reforms; 3) radical community practice, which is built on the assumption that inequality exists and that radical transformation of individual consciousness and social systems is the ideal goal of community practice (Thomas, O'Connor, \& Netting, 2011). It is our standpoint and others' that we are currently in an era of traditional community practice, characterized by a reliance on the scientific method, focus on objective ways of knowing, and a goal of maintaining the status quo through minor reforms (Brady, 2012; Thomas, O'Connor, \& Netting, 2011). While traditional community organizing is not a new paradigm, its return to prominence as the dominant guiding paradigm for professional practice indicates a shift away from the radical paradigm of community practice that was prevalent in the $1960 \mathrm{~s}$ and $70 \mathrm{~s}$ and toward a more positivistic mode of practice (Brady, 2012; Thomas, Netting, \& O'Connor, 2011; Rothman, 2007). While it is not accurate to say that neoliberalism is to blame entirely for the shift from radical to traditional community organizing, it is fair to say that neoliberalism has influenced and perpetuated this change in community organizing.

In the remaining portion of the literature review, the effects of neoliberalism on community organizing will be analyzed and explored in the three distinct areas previously mentioned, where the effects of neoliberalism can most easily be seen playing out in the context of community organizing: evidence-based practice as the manifestation of the dominant postpositivist paradigm; the shift away from acknowledging the importance and viability of social movements; and the professionalization of community organizing. 


\section{Evidence-based Practice}

While evidence-based practice (EBP) has been influential in social work for the past ten years, its prevalence has been most apparent in clinical social work (Rubin \& Babbie, 2011). EBP is a process that follows the scientific method and emphasizes interventions and practices developed through empirical research by the recommendations of experts (Drake \& JohnsonReid, 2008). The underlying values of EBP mirror those of post-positivism, including the belief that science and research are value-free and/or those values can be held in check by a rigorous research design (Rubin \& Babbie, 2011).

By emphasizing what is proven rather than what it possible, EBP also promotes the notion that change occurs incrementally and that community-based interventions should target change within the system as opposed to transforming systems (Brady, 2012; Mullaly, 2007). Colleges, universities, and professional programs are thus emphasizing EBP in mission statements, curriculum, course objectives, and grading rubrics in order to ensure that EBP is adopted by practitioners across disciplines (Rubin \& Babbie, 2011). While EBP has been embraced by some community organizers, educators, and scholars, others have met EBP with criticism and resistance for not being flexible and open enough to be useful in community-based interventions that seek to disrupt the status quo and transform systems, and not flexible enough to be helpful in organizing efforts where power dynamics, histories, and context are highly valued (Brady, 2012; Fisher \& Shragge, 2000; Fisher, Weedman, Alex, \& Stout, 2001).

\section{Social Movements}

Another area deserving of attention in critical community practice is the fostering of social movements (Goldberg, 2012; Healy, 2008; and Pyles, 2010), defined here as sustained community organizing toward a long-term goal or set of goals (Snow, 2004). Our national history in the U.S. speaks to the importance of social movements, e.g., women's suffrage, organized labor, civil rights, and gay rights (Garvin \& Cox, 2001; Piven, 2006). While strategies grounded in incremental short-term social change outcomes are important aspects of community practice, social movements provide longer lasting impact on people, communities, and overall society through sustained community building, pressure on the status quo, and empowerment related gains (Lee, 2001; Payne C. M., 1995; Piven, 2006). Social movements, with a focus on radical individual and societal change, give voice to citizens, challenges inequality, and leads to the transformation of oppressive systems (Reisch, 2005; Piven, 2006). It is of concern that the education of those entering the fields of critical community practice is weighted more heavily toward capacity building, community development, and other traditional modes of community organizing, while de-emphasizing strategies undergirded by visions of new social paradigms that value subjectivity, context, and radical change (Evans, 2011; Fisher \& Shragge, 2000). 


\section{The Professionalization of Community Organizing}

The history of community organizing is rich in case studies and historical accounts of average citizens and grassroots movements working towards social change; however, since the 1920s, community organizing, as most of social work, has experienced the consequences of professionalization (Garvin \& Cox, 2001; Piven F. F., 2006; Piven \& Cloward, 1977) Blundo (2009) states that the preoccupation with problems, human deficits, pathologies, and what is broken has dominated the social work profession since its inception and continues throughout its current development in the form of problem-focused models. Additionally, through the founding of the National Association of Social Workers in 1955, further oversight was given to social workers engaged in community organizing practice through their code of ethics (National Association of Social Workers, 2008). The NASW, along with the Council on Social Work Education (CSWE), lobbied heavily in all fifty states for regulation and licensure for professional social workers, which led to mandates in all fifty states by the early 2000s (Counsel on Social Work Education, 2012). Subsequently, the formation of the International Federation of Social Workers (IFSW), along with the International Association of Schools of Social Work (IASSW), provided similar, however less stringent, oversight to community practice globally (Healy, 2001; International Federation of Social Workers, 2005).

The results of social work and other helping professions becoming regulated have undoubtedly been positive on many fronts related to client services and ethical practice; however, there are also concerns that professionals may be knowingly and unknowingly marginalizing communities (Bar-On, 1999; Brady, 2012). Additionally, the professionalization of community organizing has led to the philosophy that professionals are leaders with the expertise that funders and governments may readily embrace in lieu of indigenous knowledge and experience possessed by local peoples (Bar-On, 1999; Lyons, 2006). Finally, professional organizers coming into communities as outsiders may displace local leadership, ignore local capacity and strengths, and disempower the very communities that they seek to help (Brady, 2012; Agenor, 2004).

\section{Critical-Foucauldian Analytic Framework}

In service of the primary goal of this paper (to analyze three areas of concern at the intersection of neoliberalism and community organizing), this section establishes a CriticalFoucauldian framework that guides the analysis. The framework builds on two theoretical perspectives - critical theory and Michel Foucault's work on social control - which, in combination, offer a useful vantage point from which to comprehend the impact of neoliberalism on community organizing. In particular, they help us account for the interplay between objective and subjective change, and the ways in which neoliberalism threatens the delicate balance between the two. Before proceeding with an explanation of the framework, it is helpful to briefly review the two perspectives on which it is based.

Critical theory, likely familiar ground for most readers, is considered a major offshoot of Marxian social thought. While orthodox Marxism emphasizes material conditions and viewed capitalist economic systems and the resulting alienation of workers as the primary cause of societal oppression, critical theorists extend this analysis to other institutions and patterns of behavior (Agger, 1992; Hardcastle, Wenocur, \& Powers, 2011; Ritzer, 2008). Critical theory connects intractable dynamics of oppression to culture, media, and educational institutions, thus highlighting the non-economic byproducts of a capitalist system. In addition to problematizing 
structures that are not directly connected to capitalist modes of production, critical theorists interrogate the process of personal subjective change as a necessary condition for systemic change (Harper \& Leicht, 2010). In the critical theorist's analysis, a shift in subjective consciousness is needed in part because certain structures and institutions are not overtly oppressive, and may appear neutral or even beneficial on the surface.

The second perspective incorporated into the framework is Foucault's work on social control, and the need for reflexivity to disrupt patterns of social control. Our application of Foucault is specifically linked to his concepts of knowledge, power, and ways in which behaviors and discourses are controlled or "disciplined" (see Foucault, 1977; Foucault, 1980; Foucault, 1984). Although the work of Foucault has been utilized broadly across many disciplines and professions, a common thread of his work is the examination of taken-for-granted aspects of the social world-specifically institutions, power, and the privileging of certain forms of knowledge (Foucault, 1980). In this paper we build on Chambon, Irving, and Epstein's (1999) application of Foucault to social work practice, and suggest that a Foucault-based approach to reflexivity can disrupt patterns of power and control, and serve as a useful foil to critical theory's emphasis on structures and systems.

The proposed framework is designed and justified with three assertions in mind. First, critical theory emphasizes both personal and systemic change, but its embrace of subjective change is often secondary to its call for structural change. Second, Foucault's perspective on knowledge, power, and social control provides an opportunity for critical reflection among community organizing practitioners and scholars. Third, community organizing practitioners and scholars are particularly well suited to utilize and critique this framework given the field's commitment to praxis and its dual emphasis on subjective and objective change. The assertions above will serve as the basis for our theoretical analysis of the impact of neoliberalism on community organizing practice.

\section{Critical Theory and Community Organizing}

Critical theory has a deep connection to community organizing that is derived from its dual emphasis on changing oppressive structures and liberating the individual from false consciousness (Hardcastle, Powers, \& Wenocur, 2011; Pyles, 2009). However, it is not entirely clear whether, and to what extent, there is room left for individual subjectivity within critical theory-based interventions in practice. The empirical evidence regarding community organizing outcomes at the individual level is scant, and conceptually scholars suggest that while the coexistence of subjective and objective realms is a defining feature of critical theory (Guba, 1990), in practice it is a challenge that is often unresolved (Burghardt, 2011). Thomas, O'Connor, and Netting (2011) point out that, "while the critical theory paradigm recognizes a subjective component, it is the drive for visible, external, objective change that characterizes the paradigm" (p. 343).

That said, certain critical theorists demonstrate an interest in subjectivity that is on par with concern for structural change. Paulo Freire, Theodor Adorno, and Herbert Marcuse exemplify this voice within proponents of critical theory. Freire (2000) is associated with deep attention to subjectivity through the process of conscientization, through which individuals "break[ing] through prevailing mythologies to reach new levels of awareness - in particular, awareness of oppression, being an 'object' of others' will rather than a self-determining 'subject'"' (Goldbard, 
2006, p.242). Adorno's (1973) subjectively-oriented strain of critical theory is seen as prefiguring postmodernist rejections of totalizing narratives (Best \& Kellner, 1991), and Marcuse (1969) clearly articulates the position that subjective transformation is a necessary precondition of revolution, and further argues that systemic change in the absence of personal change will lead to new forms of oppression and domination (Agger, 1992).

Despite the efforts of these subjectively oriented critical theorists, given the structural change imperative embedded in the theory, it is a challenge for practitioners and scholars to attend adequately to individual transformation. One plausible reason this occurs is that the sheer magnitude of systemic injustice makes change at the personal level seem inconsequential at times. Here, however, we heed Marcuse's (1969) caution not to diminish the importance of personal agency and in doing so run the risk of allowing one oppressive system to replace another. Through a brief examination of the insidious nature of neoliberalism we next make the case that critical theory can fall short and that Foucault's analysis helps us adequately attend to individual change. Put differently, in our effort to better understand the impact of neoliberalism on community organizing, we next argue that the introduction of Foucault as an analytic tool is a logical next step in building on the work of subjectively minded critical theorists.

\section{Critical Reflection through Foucault}

Despite the abovementioned subset of critical theorists' more subjective orientation, some doubt remains regarding its usefulness in not only attending adequately to personal transformation, but also honoring the complexities and understanding the challenges of today's globalized, privatized world of rising inequality and instability (Mullaly, 2001). More exactly, the impact of neoliberalism on the venues of civil society and poverty policy expose the weakness of critical approaches and the usefulness of Foucauldian analysis. An increasingly privatized and contract-based civil society, along with a retrenched global welfare state, are strong clues that the twin approaches of consciousness raising and structural transformation prescribed by critical theory are losing ground to the ascendant doctrine of neoliberal individualism (Hasenfeld \& Garrow, 2012; Choudry \& Shragge, 2011). The harsh impact of this doctrine is most acutely felt among the poor. Four decades after Piven and Cloward's (1971) seminal work in this arena, poverty policy has moved past mere regulation and toward an elaborate blend of discipline, punishment, and market-based coercion (Soss, Fording, \& Schram, 2011).

In addition to civil society and poverty policy, a third site of profound neoliberal impact is higher education (Ball, 2012; Kascak \& Pupala, 2011; Suspitsyna, 2012). For those privileged to study and teach community organizing for a living, the prospect of doing so within an institution governed by free-market principles creates a paradox. It also means that vigilance, creativity, and reflexivity are needed to understand who ultimately benefits from our work, and the true impact of our activities on the world around us.

Foucault's analysis of social control emphasizes the role of institutions in maintaining conformity, and the role of individuals in complying with or resisting behaviors deemed normative. This analysis hinges on the two-sided premise that we are trained both to comply and to convince ourselves that we have a choice in the matter. In the same way that neoliberalism has become a ubiquitous (and like air, hard to notice) influence on higher education, social welfare, and other institutions, Foucault (1984) argues that our own actions and inactions can be invisible yet still implicated in the neoliberal project (Chambon, 1999). This 
parallel process - seeing the broader forces at work while also seeing how we as individuals contribute to them - is particularly relevant to social workers, community organizers, and others ostensibly committed to social justice, because it forces us to examine our own moral positioning and reflect on how we might be contributing to systems and discourses of injustice. Chambon (1999) refers to these reflexive processes as "unsettling" inquiries (p. 53), which have the potential to "[make] the familiar visible" (p. 54). Certainly critical theory emphasizes similar dynamics and goals by theorizing 'false consciousness' and other concepts associated with alienation, but Foucault's methodologies help highlight the micro-level implications and examples of social control.

\section{The Analytic Framework}

In the sections below, three trends at the intersection of community organizing practice and education are analyzed: the growing role of evidence-based practice; professionalization; and the decreasing attention given to social action as a viable method of intervention. Critical theory, along with Foucault's work, contributes greatly to our understanding of how these trends are situated within neoliberal social and political structures, and how alternative versions of these structures or institutions are envisioned.

Table 1

Critical-Foucauldian Analytic Framework

\begin{tabular}{|c|c|c|c|}
\hline & Element \#1 & Element \#2 & Element \#3 \\
\hline $\begin{array}{l}\text { Key } \\
\text { question(s) }\end{array}$ & $\begin{array}{l}\text { What might structures and } \\
\text { institutions (e.g., higher } \\
\text { education, nonprofit } \\
\text { organizations) look like that } \\
\text { engage evidence-based } \\
\text { practice, professionalization, } \\
\text { and social movements in a } \\
\text { different way? }\end{array}$ & $\begin{array}{l}\text { What must community } \\
\text { organizing practitioners, } \\
\text { scholars, or stakeholders } \\
\text { do to "unsettle" our } \\
\text { relationship with } \\
\text { neoliberal perspectives on } \\
\text { evidence-based practice, } \\
\text { professionalization, and } \\
\text { social movements? }\end{array}$ & $\begin{array}{l}\text { How would our role } \\
\text { change, expand, or } \\
\text { contract in this newly } \\
\text { imagined structural reality? } \\
\text { How might we do good, } \\
\text { and how might we cause } \\
\text { harm in this imagined } \\
\text { reality? }\end{array}$ \\
\hline $\begin{array}{l}\text { Theoretical } \\
\text { perspective }\end{array}$ & Critical & Foucauldian & Critical and Foucauldian \\
\hline $\begin{array}{l}\text { Epistemologic } \\
\text { al Orientation }\end{array}$ & $\begin{array}{l}\text { Objectivist, proposing } \\
\text { alternative structures that } \\
\text { would be objectively better } \\
\text { (through the critical lens) than } \\
\text { existing ones }\end{array}$ & $\begin{array}{l}\text { Subjectivist, examining } \\
\text { one's role in reinforcing } \\
\text { dynamics of domination } \\
\text { and oppression }\end{array}$ & $\begin{array}{l}\text { Objectivist-Subjectivist, } \\
\text { considers the ground-level, } \\
\text { micro-political implications } \\
\text { of structural change }\end{array}$ \\
\hline Major themes & Justice, social change & $\begin{array}{l}\text { Reflexivity, unsettling } \\
\text { inquiry }\end{array}$ & $\begin{array}{l}\text { Praxis, challenging } \\
\text { orthodoxy }\end{array}$ \\
\hline
\end{tabular}


The first element of the analytic framework above (Table 1) is grounded in critical theory and based on the question, What might structures and institutions look like that engage evidencebased practice, professionalization, and social movements in a different way?

The second element of the analytic framework is drawn from the Foucauldian emphasis on 'unsettling inquiry' with the goal of 'making the familiar visible' regarding one's own complicity in replicating and reinforcing injustice related to these three trends. The focus here is on microlevel behaviors and actions that must be identified, named, and altered moving forward. The key question here is, What must community organizing practitioners, scholars, or stakeholders do to "unsettle" our relationship with neoliberal perspectives on evidence-based practice, professionalization, and social movements?

The third element involves an attempt to identify strategies by which the alternative models that emerge from the first element might be engaged, analyzed, and critiqued using a process similar to the second element. In other words, if a particular institutional or structural change is proposed to address, for example, the growing influence of EBP, how might we engage that proposed change in a reflexive way that helps us imagine the dangers (or opportunities) that might lurk (or arise) at the micro-political level if the alternative to EBP were actually implemented. This element requires a willingness to challenge the critical orthodoxy in order to expose oppressive possibilities in alternative structures and institutions. Suitable questions in this vein are, How would our role change, expand, or contract in this newly imagined structural reality? How might we do good, and how might we cause harm?

\section{Evidence-Based Practice}

Evidence-based practice (EBP) is a major force in professional community organizing. EBP is the direct manifestation and result of post-positivistic values. EBP in practice can be seen as an extension of the medical model to community organizing, social work, and other professions in that it calls on practitioners to identify causal connections between interventions and alleviation of specific problems. While EBP provides one worldview for how to arrive at best practice, it is not able to address contextual and historical dimensions often at play in community organizing, nor does it provide room for radical change and system transformation; common aims of critical community practice (Boehm \& Cnaan, 2012; Fisher \& Shragge, 2000).

\section{Problem Analysis}

The common sequential process that proponents of EBP layout are as follows: 1) formulate a research question; 2) research relevant literature; 3) assess the literature; 4) identify most appropriate intervention based on evidence; 5) implement the intervention; and 6) evaluate the intervention to confirm or refine EBP (Rubin \& Babbie, 2011). EBP as outlined previously, follows a linear rational process that provides the best treatment options for patients with a specific typology of symptoms, but at the expense of accounting for culture, context, and difference (Tervalon \& Murray-Garcia, 1998). While proponents indicate that most problems associated with EBP are due to the poor implementation of EBP by organizations and practitioners lacking capacity and expertise to successfully use it, others have pointed out that the underlying values of EBP are at direct odds with the values of critical community organizing (Brady, 2012; Fisher \& Shragge, 2000; Miller, 2010). 


\section{Critical-Foucauldian Analysis and Recommendations}

Although evidence-based practice has become the dominant process for guiding and informing community organizing, alternative visions must be conceptualized with the help of the CriticalFoucauldian framework. EBP as the dominant process guiding professional community organizing must be re-conceptualized and replaced within professional practice and education. Community organizing institutions are used in this paper to refer to the major societal structures that control how community organizing is conceptualized and practiced, such as colleges and universities that build much of the knowledge base for what is considered best practices in community organizing, governments and foundations that fund community organizing, and entities that provide oversight or mandates as to what constitutes good professional practice (e.g., National Association of Social Workers, American Psychological Association, International Federation of Social Workers, Council on Social Work Education).

Despite the perpetuation of EBP by the before-mentioned societal institutions, other perspectives exist that conceptualize communities as dynamic entities. Additionally, these alternative perspectives promote professional organizing as dialectical and dynamic, emphasize the process of organizing as much as outcomes, and view community organizing as capable of attaining not just reformative change, but radical transformative change (Aronowitz, 2003; Butcher, Banks, Henderson, \& Robertson, 2007; \& Piven, 2006). It is our stance and that of others that EBP must be replaced as the "best practice" process within community organizing institutions in order to allow for a broader range of possibilities for communities and organizers alike (Brady, 2012; Fisher \& Shragge, 2000).

One potential option for replacing EBP in dominant institutions can be found in the utilization of critical adult education and the formation of folk schools, freedom schools, citizenship schools, and other entities that exist separately from mainstream community organizations and government entities. Folk schools, freedom schools, and the like have helped provide critical adult learning, literacy, organizing skills, leadership development, and other resources to local peoples seeking to challenge systemic inequality and the status quo (Garvin \& Cox, 2001; Horton, 1998; Lange, 2004). While once popular across Europe and the U.S., many folk schools and similar institutions ceased to exist following the more turbulent times of the 1960s and 70s (Levine, 2004). The reasons that these institutions ceased to exist or rapidly declined in numbers across the U.S. and Europe is not entirely known, but some authors suggest that the increasing presence of neoliberal policies and their consequences played a large role in the demise of institutions promoting critical adult education in the U.S. and abroad (Levine, 2004).

Critical adult education institutions provide an excellent frame of reference for replacing current EBP institutions and structures. Folk schools and similar institutions were built from the premise that it was not possible to transform systems from within nor could individuals experiencing marginalization rely on professional organizers and workers from inside these institutions to change them (Horton, 1998; Levine, 2004). One well-known U.S. folk school, the Highlander Folk School (currently known as the Highlander Research and Citizenship Institute), has provided training, support, and resources to countless local and well-known leaders of the U.S. freedom (civil rights), labor, and women's rights movements. While Highlander and similar institutions welcomed professionals to help provide expertise, monetary resources, and social support to their causes, professionals were expected to work side by side with non- 
professionals as equals (Morris, 1984; Horton, 1998; Payne C. M., 1995). Through changing the culture and relationship between professionals and non-professionals, it created an atmosphere of mutual learning, respect, and support (Horton, 1998; Levine, 2004).

While identifying and acknowledging the problem of EBP in professional organizing is an initial step, other tasks also must be undertaken in order to unsettle EBP perspectives within institutions. Firstly, professional community organizers, scholars, and educators must begin demonstrating intellectual courage from within dominant neoliberal institutions that promote EBP. Those of us belonging to professional associations and who present at academic and professional conferences must begin presenting more critical and alternative standpoints in order to change the current discourse. Scholars and researchers must work with practitioners and community members to write and publish alternative and critical discourses related to the limitations and negative consequences associated with EBP.

Secondly, the use of praxis provides us with another tangible tool for helping unsettle the EBP within community organizations, institutions of higher learning, and NGOs. Praxis has been conceptualized in a variety of ways, but has conceptual roots stemming back to Plato, Aristotle, Marx, Gramsci, Lukács, Arendt, and Freire, each of whom emphasized the importance of critical reflection upon everyday actions, thinking, and feeling for the purpose of gaining an in-depth understanding that can be utilized for personal and/or social transformation (Fay, 1996; Freire, 1970). Praxis has also been conceptualized in many practice-oriented disciplines such as community psychology, adult education, social work, and nursing as the practice of thinking about theory and practice for the purpose of improving both (Boehm \& Cnaan, 2012; Payne, 2005).

Finally, our analysis utilizes tenets from critical and Foucauldian theories, and asks how the roles of community members, educators, practitioners, and researcher/scholars would need to change as well as the potential benefits and harm associated with changing roles. The biggest change in roles that will take place as EBP is critiqued and replaced as the dominant process guiding professional community organizing will occur among professionals and nonprofessionals. Professionals will take on an increased role in reforming and transforming organizations and institutions that are rooted in neoliberal values that support EBP. Professional practitioners, scholar/researchers, and educators will exercise greater intellectual courage and praxis in order to disrupt and challenge the dominant discourse of EBP within societal institutions. Subsequently, nonprofessionals will share responsibility for challenging what is considered legitimate knowledge in community organizing by creating alternative spaces for community organizing in lieu of EBP-guided processes.

Additionally, professionals in community organizing will decrease control and power over local efforts, while instead providing support to community-based efforts and movements with aims of transforming current institutions of community organizing. Non-professional organizers will take on the role as experts, while local knowledge, practice wisdom, and critical praxis will replace neoliberal values that promote the EBP process as the dominant perspective guiding community organizing. 


\section{Social Movements}

Despite the success of social movements in achieving structural and systemic change, they are not emphasized in curricula or in practice to the same degree as top down, capacity building, and incremental change variations of community organizing are emphasized (Evans, 2011; Fisher \& Shragge, 2000). A reduced emphasis on strategies of organizing with incremental change and capacity building goals is not called for, and the teaching and fostering of social movement interventions should be a first-order concern alongside these other approaches.

\section{Problem Analysis}

The de-emphasizing of social movements, particularly those that might be described as "transformative" (Pyles, 2009), comes at an inopportune time. Three decades marked by an eroding social safety net and increasingly ineffectual and polarized political system, and capped by the great recession that started in 2008, have made the need for sustained organizing efforts particularly acute (Goldberg, 2012).

In order to take on a meaningful role in the major public questions of our time, community organizers must have the capacity to not only challenge aspects of the existing systems related to social welfare, philanthropy, and political economy, but also the ability to facilitate and support alternative visions of resource distribution and policy development. Snow (2004) extends this argument by challenging the notion that social movements are limited to contesting at the political level; rather, he argues, in addition to carrying out a contesting function, social movements can act to challenge dominant structures and, in some cases, mobilize participants to dramatically transform or eliminate those structures altogether. In other words, we must not only extend the conception of community organizing to include a more sustained effort over time, but also further examine assumptions regarding the goals of these sustained efforts. Social movements can help chart and mobilize toward alternative cultural and sociopolitical courses of action, and need not be restricted to confronting aspects of what currently exists.

\section{Critical-Foucauldian Analysis}

If we accept the premise that a particular moment of opportunity exists for the encouragement of social movements within community organizing practice, from the proposed CriticalFoucauldian perspective the first question then becomes how institutions and organizations might engage differently with the generation, support, and analysis of these movements. In this institutional sphere, one set of considerations relates to the organizational homes traditionally considered most receptive to this work. While civil society organizations, e.g., NGOs, nonprofits, and voluntary organizations, have done much to further the cause of social justice, neoliberal hostility towards organizations that take part in advocacy and collective action means that practitioners must also be prepared to engage with collaborative, decentralized movements such as Occupy Wall Street and the global justice movements (Cordero-Guzman, Martin, Quiroz-Becerra, \& Theodore, 2008; Gautney, 2012; Hasenfeld \& Garrow, 2012; Pyles, 2010). This means that practitioners employed by organizations must consider creative strategies of mutual support with other organizations as well as non-organizational actors. Individuals and organizations must also develop methods of circumventing or challenging the institutional 
biases against funding community organizing in general and social movements in particular (Lethabo-King \& Osayande, 2007).

Other institutional considerations relate to higher education. Students being educated in the fields of community psychology and macro social work, for example, find themselves completing their degrees with relatively little foundational knowledge about social movements in comparison to what they learn about discrete, localized versions of community organizing (Evans, 2011; Fisher \& Shragge, 2000). The increasingly commodified environment of higher education (Ball, 2012) creates pressure to prepare job-ready graduates, oftentimes at the expense of equipping students with a package of skills and knowledge that is geared toward social change rather than marketability (Brown, 2011). For those working in academic institutions, the challenge becomes how to create space to problematize the premise that education is equivalent to job training.

The second question to consider is how individual stakeholders can examine their own behavior in relation to neoliberal institutions. In both civil society and higher education, we must enter into a dialogue about our own roles in perpetuating market-based approaches to the exclusion of social movements. How do we as paid scholars and practitioners benefit by tethering community organizing education and practice to tightly managed outcomes as opposed to broader, less certain movement building processes? Will our expertise be valued more highly if we hold a specific key to a specific lock, even if that specificity precludes the border-crossing and role confusion that come with the territory of building movements? These are not questions with clear answers, but Foucauldian analysis would have us ask them in order to examine and unsettle narratives related to our role in the neoliberal approach to social control. In this analysis, neoliberal hostility to social movements is not perpetrated by an objectified other, and we must all bear responsibility for the parts we play and the benefits we reap in the current regime.

The third question in the analytic framework examines the potential for further reproduction of instances of micro-violence even within structures and institutions that prioritize social movements. One can, for example, imagine that the very existence of civil society and higher education institutions creates fertile ground for certain types of knowledge to take precedence over others. Further, would practitioners in civil society organizations and those in academia wholeheartedly endorse subverting or exiting social movement approaches, which, in theory, could lead to the dismantling of the institutions by which they are employed?

A general strategy that may address these intrinsic dilemmas is the development of "third spaces" explicitly intended to explore ideas in environments relatively free of institutional pressures. One conception of such spaces comes from Habermas $(1984,1987)$ and involves the combining of intersubjectivity with several attributes of rational communication, including reflexivity and sincerity. Habermas' formulation suggests a starting point for conceptualizing a voluntary space outside of civil society organizations and the academy within which to cultivate and support social movements. An example of such a space would be a group of university faculty and students, community practitioners, and grassroots community members meeting to discuss and analyze how funds from a local community foundation are distributed, and to what extent those funds benefit the community as opposed to the university and nonprofit professionals who directly receive the grants. The creation of alternative spaces without consciousness raising and cultural humility, however, will likely lead to the same power 
dynamics and status quo rhetoric that currently exists in dominant institutions; thus not only do the spaces for critical dialogue about community organizing and social movements need to change, but so do the ways in which professionals, nonprofessionals, academics, and researchers interact with one another. Any attempt to create an alternative and safe place to question the status quo must begin by ensuring that there are more nonprofessionals participating than professionals in order to shift the power dynamics that exist between these groups. Additionally, training related to cultural humility and anti-oppressive dialogue are needed for all participants in alternative spaces to respectfully communicate with one another as equals, while respecting the ideas and standpoints of one another (Adams, Bell, \& Griffin, 2007; Fithian, 2009).

In practice, the proposed analytic framework may help bring hard but necessary questions to the forefront about our reluctance to emphasize and engage in social movements. As nonprofits and universities face increasing financial demands and other pressures to produce immediate results, tensions will continue to arise between the career paths of professionals and the development of long-term, multi-faceted social movements. As discussed in greater depth in the following section, these tensions present opportunities to consider whether our allegiance ultimately lies with the institutions to which we are connected or the movements we want to create and develop. It should be kept in mind that power dynamics do not cease to exist when physical locations change, which place the onus on professionals and scholars to engage in critical reflexivity and acknowledge their privilege before entering these collaborative spaces.

\section{The Professionalization of Community Organizing}

The mainstreaming of community organizing into the public consciousness by political forces, non-profit organizations, and social and mainstream media creates fundamental power shifts in the methods, directions, and priorities of practice. This section will discuss the influence of neoliberalism on the ever-emerging trend of the professionalization of community organizing through the use of a Critical-Foucauldian analysis. We will discuss the paradox caused by the pervasive neoliberal drift in the philanthropic and nonprofit sectors wherein professional community organization initiatives are typically funded, managed, and often controlled at the expense of marginalizing and excluding local knowledge and nonprofessionals. Implications for practice are explored in order to guide practitioners as to how to mitigate the negative effects of the professionalization of community organization.

\section{Problem Analysis}

Community organizing has historically focused on local peoples working together to create social change (Brown, 2006). Although local community organizing efforts are frequently discussed in professional literature, it is relatively recent that community organizing has become a sought after profession or area of practice (Fisher \& Shragge, 2000; Gamble \& Weil, 2010). Social work came out of the severe economic inequalities and class struggles of the industrial revolution, and it is inextricably intertwined with the early histories of the philanthropic and nonprofit sectors (Axinn \& Stern, 2005; Smith, 2007). Before the industrial revolution, few formal organizations existed to address social problems (Axinn \& Stern, 2005). This began to change as the accelerating mechanization of industry and violent conflicts of the late nineteenth century gave rise to social problems, such as increased poverty, harsh labor conditions, and various other economic oppressions. Organizations, many religious and run by local elites, 
formed to give aid to those they viewed as deserving of help. The basis of which was subjective to various moral ethical standards (Slaughter, \& Silva, 1980). This was the inception of the professionalization of the helper. These early charity service organizations began to hire paid staff, formalize standards of practice, and organize themselves as institutions (Garvin \& Cox, 2001; Reisch, 2005). Even given the tumultuous historic period, with harsh working conditions, oppressive economic inequality, and worker's struggles, these philanthropic charity organizations did not advocate for higher wages, organize for women's right to vote, or challenge entrenched power dynamics (Addams, 1910; Piven \& Cloward, 1977). Although they worked to decrease the impact of low wages, poverty, and other horrors of the unregulated capitalist industrial revolution, as a whole, these organizations did not organize to dismantle these entrenched structural elements of power (Smith, 2007).

During the same time that charity organizations and social welfare efforts began to take hold and recognize the need for professional training in the areas of addressing poverty, mental illness, and other environmental and individual problems, nonprofessionals were working in locally and nationally to build capacity, raise consciousness, and work towards addressing unjust systems (Piven \& Cloward, 1977; Piven, 2006). Most local community organizers were trained by other seasoned organizers and through adult education mechanisms such as freedom schools and folk schools (Levine, 2006). While professional organizers and social service workers were forced to operate under mandates from government and NGOs, nonprofessionals were able to operate without regard to these status quo systems, which resulted in the birth of social movements, targeted social action, increased community capacity, and collective socio/political empowerment (Morris, 1984; Payne C. M., 1995; Solomon, 1976).

\section{Critical-Foucauldian Conceptual Analysis}

The three questions proposed in the Critical-Foucauldian framework relates to reconceptualizing how professionalization might look differently in newly created or transformed institutions of community organizing (colleges and universities, NGOs, social service agencies, etc.) and how academics and practitioners alike might work to uncover the negative effects of professionalization in order to open a broader discourse about the potential harm that can come about if professionalization is allowed to persist unchanged in community organizing. Finally, with any reforms or transformations come changes in the roles that players in community organizing will undergo as well as the direct consequences that come about from them.

The first question: What might structures and institutions look like that engage in professional organizing in a different way? This question calls for envisioning a more idealized view of professional organizing, and then working backward to examine the steps it would take to get to a place where professional organizing could operate justly, reflect the voice of community constituents, and be an effective tool for social change. While many authors (see Hardcastle, Powers, \& Wenocur, 2004; Netting, Kettner, \& McMurtry, 2008; Rothman, 2007) may suggest small-scale reforms within the current system, critical theory would suggest that in order to address the professionalization of community organizing, it is necessary to transform the current system (Mullaly, 2007).

One of the first and most vital components of change related to professional community organization is the need to create and promote institutions where non-professional organizers are provided the necessary resources and structures for engaging in community organizing. 
Local organizers and people would thus become the experts over addressing social problems in the community. Professional organizers would either need to work in collaboration with nonprofessional organizers in spaces where non-professional organizers had all or the majority of decision making power over institutional decision making, or accept the idea that nonprofessional organizers may need their own spaces separate from those of professional organizers. Professional organizers must learn to utilize the philosophy of cultural humility in order to accept the idea that it is acceptable and even necessary for non-professional organizers to have separate spaces and to respect the fact that they may not always want professional allies working in the same spaces as a result of historical legacies of marginalization, current power inequalities, and a need to build intra group solidarity first, before allowing outsiders into their spaces (Bullard, 2007; Johnson, 2006). Additionally, community-led institutions of organizing must build the necessary capacity to become more self-sufficient and not reliant on grant funding from government or large foundations in order to have greater control and autonomy over their mission and work. Professionals can still play active roles in citizen-led community organizations as they possess different types of expertise and access to networks of elites and decision makers; however, professionals must begin taking their cues from nonprofessional organizers as to what their role should be, if they are to be truly supportive of any effort to counter or transform the professionalization of community organizing.

The second question within the framework is a more difficult one to wrestle with, because it is less objective. The first dealt with looking specifically at what can be changed to transform the current system. The second question directly challenges practitioners, scholars, and other stakeholders to examine our role in reinforcing the dynamics of oppression. What must community practitioners, scholars, and stakeholders do to "unsettle" our relationship with neoliberal perspectives on professionalization?

In order to unsettle ourselves, professional community practitioners and scholars in the field must interrogate several key aspects of the status quo that help to maintain the professionalization of community organizing. Professional community organizers must question the motivation behind the professionalization of community organizing, question the role that privilege plays in maintaining inequality between professional and non-professional organizers, and how the systems and institutions that we invest in, work for, and belong to through professional memberships help to further co-opt non-professional community organizing in order to legitimize professional organizing.

One very poignant way that some organizers have unsettled the current system has been through facilitating grassroots fundraising, taking part in developing communitarian-based economic systems (barter economies), and speaking out about the injustices perpetuated by the neoliberal rooted nonprofit industrial complex (Choudry \& Shragge, 2011; Kivel, 2007). Many of these same organizers have refused to accept payment for their services accepting that in order to do organizing, one must not expect payment, and in some cases forgo payment in order to create an organization that can survive and thrive (Guilloud, \& Cordery, 2007). Professional organizers choosing to speak to power and disrupt the dominant discourse present in mainstream community organizations often face resistance, threats from administration, and the possibility of losing their jobs (Wagner, 1990). Despite the potential harm that can come to professional organizers choosing to call into question the professionalization of community organizing, it is those in positions of privilege as professionals, academics, and scholars that 
must begin the alternative discourse and challenge the professionalization of community organizing (Fisher, Weedman, Alex, \& Stout, 2001).

Finally, the last question posed in the Critical-Foucauldian framework asks how might the roles of those involved change as a result of changing the institutions promoting the professionalization of community organizing as well as the positive and negative consequences associated with said changes. The changing roles would most affect professional and nonprofessional organizers. If community organizations were transformed to be led by nonprofessionals, or reordered to establish more balance in power between professional and non-professional organizers, the role of expert would shift from professional to nonprofessional. Professionals would still have expertise, but utilize their skills in support of non-professional organizing expert. Leadership roles would shift from professionals and chosen administrators and boards to non-professional and community leadership and oversight. Educators and accreditation bodies overseeing curriculum in community organizing would become co-teachers with local leaders and nonprofessionals in order to properly train students to create competencies that are in line with the new era of community organizing. Non-professional organizers would begin taking on roles in developing competency standards for ethical community practice. Non-professional organizers may also be asked to team-teach or teach alongside professional academics in order to ensure proper content and ethics are taught in community organizing courses.

The potential positive consequences of nonprofessionals taking on greater roles in leadership, teaching, and curriculum development for community organizing is that non-professional organizers will have great power and decision-making ability and will thus become the expert, while professionals will still be valued for the expertise that they bring to the table, but will learn to share and balance their expertise with the practice wisdom and insider knowledge of local organizers.

Subsequently, negative consequences could stem from a state of transition and role confusion where professionals and nonprofessionals are seeking to understand what roles and expectations they possess. Professional organizers having invested years in formal education may resent nonprofessionals having greater power and influence, and thus feel as though their expertise is being minimized. Non-professional organizers may face too high of expectations and pressure to attain positive outcomes without possessing the necessary financial support and resources needed to be successful. Overall any radical transformation in societal structures and thinking that leads to a new order in community organizing where nonprofessionals have greater power than professionals will result in changing roles, each with potential positive and negative consequences.

\section{Conclusion}

Community organizing and neoliberalism are fundamentally at cross-purposes. While true grassroots progressive community organizing privileges locally constructed truth and addresses systemic barriers to social justice, neoliberalism values objective truth and market discipline. In this article we have presented three troubling examples of the neoliberal doctrine's impact on community organizing practice-the post-positivist promotion of evidence-based practice as a mandate for professional organizing, the de-emphasizing of social movements, and the professionalization of community organizing. Each of these examples comes with a hidden cost 
of marginalizing and limiting professional and non-professional organizers. Through critically analyzing the impact of neoliberalism on community organizing and utilizing critical and Foucauldian theories, we have provided some initial recommendations for practitioners seeking to challenge the current status quo of community organizing. Although the authors' steps in this paper are a starting point, much more critical discourse and action is needed to truly unsettle and transform the current state of community organizing into something more reminiscent of its radical and transformative roots as a mechanism for attaining social change.

\section{Contact Information:}

Shane R. Brady

Anne and Henry Zarrow School of Social Work

University of Oklahoma

700 Elm Avenue City

Norman, OK 73019

Email: srbrady78@gmail.com

\section{References}

Adams, M., Bell, L. A., \& Griffin, P. (Eds.). (2007). Teaching for diversity and social justice. New York: Routledge.

Addams, J. (1910). Twenty years at Hull-House. New York: MacMillian.

Adorno, T. (1973). Negative dialectics. London: Routledge.

Agenor, P.-R. (2004). Does globalization hurt the poor? International Economics and Economic Policy, 1, 21-51. doi:10.1007/s10368-003-0004-3

Agger, B. (1992). The discourse of domination: From the Frankfurt School to postmodernism. Evanston, IL: Northwestern University Press.

Ahn, C. (2007). Democratizing American philanthropy. In INCITE! Women of Color against Violence (Ed.), The revolution will not be funded: Beyond the non-profit industrial complex (pp. 63-78). Cambridge, MA: South End Press.

Alinsky, S. D. (1971). Rules for radicals: A pragmatic primer for realistic radicals. New York: Random House.

Aronowitz, S. (2003). The new social movements and class. In S. Aronowitz (Ed.), How class works: Power and social movement (pp. 141-170). New Haven, CT: Yale University Press. 
Axinn, J. and Stern, H. (2005). Social Welfare: A History of the American Response to Need. (6th ed). White Plains, New York: Longman.

Ball, S. J. (2012). Performativity, commodification and commitment: An I-Spy guide to the neoliberal university. British Journal of Educational Studies, 60(1), 17-28. Retrieved from http://dx.doi.org/10.1080/00071005.2011.650940

Bar-On, A. (1999). Social work and the missionary zeal to whip the heathen along the path of righteousness. British Journal of Social Work, 29(1), 5-26. Retrieved from http://bjsw.oxfordjournals.org.proxy.library.vcu.edu/content/29/1/5.short

Best, S., \& Kellner, D. (1991). Postmodern theory: Critical interrogations. New York: Guilford.

Blundo, R. (2009). The challenge of seeing the world we think we know: Learning strengths based practice. In David Saleeby (Ed.), The Strengths Perspective in Social Work Practice (5th Ed.). NY: Pearson Education, Inc: 26-46.

Boehm, A., \& Cnaan, R. A. (2012). Towards a practice-based model for community practice: Linking theory and practice. Journal of Sociology and Social Welfare, XXXIX(1), 141-170. Retrieved from http://www.wmich.edu/hhs/newsletters_journals/jssw/index.htm

Brady, S. R. (2012). Discovering how community organizing leads to social change: Developing formal practice theory for social workers engaged in empowering community organizing (Doctoral dissertation, Virginia Commonwealth University). Available from ProQuest Dissertations and Thesis database. (UMI No. 3546921).

Brown, M. J. (2006). Building powerful community organizations. Arlington, MA: Long Haul.

Brown, W. (2011). The end of educated democracy. Representations, 116(1), 19-41. doi: 10.1525/rep.2011.116.1.19

Bullard, R. (2007). The black metropolis in the twenty-first century: Race, power, and politics of place. NY: Rowman \& Littlefield.

Burghardt, S. (2011). Macro practice in social work for the 21st century. Thousand Oaks, CA: Sage.

Burrell, G., \& Morgan, G. (1979). Sociological paradigms and organisational analysis. London: Heinneman.

Butcher, H., Banks, S., Henderson, P., \& Robertson, J. (Eds.). (2007). Critical community practice. Bristol, U.K.: Policy Press.

Campbell, B. (2012). Richmond's unhealed history. Richmond, VA: Brandylane.

Chambon, A. (1999). Foucault's approach: Making the familiar visible. In A. Chambon, A. Irving, \& L. Epstein (Eds.), Reading Foucault for social work (pp. 51-82). NY: Columbia University Press. 
Choudry, A., \& Shragge, R. (2011). Disciplining dissent: NGOs and community organizations. Globalizations, 8(4), 503-517. doi:10.1080/14747731.2011.585855

Cooke, A., \& MacSween, A. (Eds.). (2000). The rise and fall of adult education institutions and social movements. The Seventh International Conference on the History of Adult Education (pp. 1-383). New York: Oxford.

Council on Social Work Education. (2012). 2008 Education and policy accreditation standards. Retrieved from http://www.cswe.org/Accreditation/2008EPASDescription.aspx

Cordero-Guzman, H., Martin, N., Quiroz-Becerra, V., \& Theodore, N. (2008). Voting with their feet: Nonprofit organizations and immigrant mobilization. American Behavioral Scientist, 52(4), 598-617. doi: 10.1177/0002764208324609

Dahlberg. (2005). The Habermasian public sphere: Taking difference seriously? Theory and Society, 34(2), 111-136. doi:10.1007/s11186-005-0155-z

Defilippis, J., \& Saegert, S. (Eds.). (2012). The community development reader (2nd ed.). New York: Routledge.

Dowie, M. (2002). American foundations: An investigative history. Cambridge, MA: MIT Press.

Drake, M., \& Johnson-Reid, M. (2008). Social work research methods: From conceptualization to dissemination. New York: Allyn Bacon.

Evans, S. (2011). Review of the book "Critical community psychology," by Carolyn Kagan, Mark Burton, Paul Duckett, Rebecca Lawthom, and Assiya Siddiquee. Global Journal of Community Psychology Practice, 2(2). Retrieved from http://www.gjcpp.org/en/review.php?issue=7\&review=11

Fay, B. (1996). Contemporary philosophy of social science: A multicultural approach. Malden: Blackwell.

Finn, J., \& Jacobson, M. (2003). Just practice: A social justice approach to social work. Peosta, IA: Eddie Bowers.

Fisher, R., \& Shragge, E. (2000). Challenging community organizing: Facing the 21st century. Journal of Community Practice, 8(3), 1-19. doi:10.1300/J125v08n03_01

Fisher, R., Weedman, A., Alex, G., \& Stout, K. D. (2001). Graduate education for social change: A study of political social workers. Journal of Community Practice, 9(4), 43-64. doi:10.1300/J125v09n04_03

Fithian, L. (2009, September 1). Anti-Oppressive principles and practices. Retrieved from http://rantcollective.com/article.php?id17

Foreign Ministry of Education and Research. (2013). Social movements. Retrieved from Media Culture Transformation: http://www.mediacultureegypt.com/

Foucault, M. (1977). Discipline and punish. New York: Pantheon. 
Foucault, M. (1980). Power/Knowledge: Selected interviews and other writings, 1972-1977. New York: Pantheon.

Foucault, M. (1984). Truth and power. In P. Rabinow (Ed.), The Foucault reader (pp. 51-75). New York: Pantheon.

Freire, P. (1970). Pedagogy of the oppressed. New York: Continuum International.

Gamble, D., \& Weil, M. (2010). Community practice skills: Local to global perspective. New York: Columbia University Press.

Garvin, C., \& Fox F. (2001). A history of community organizing since the civil war with special reference to oppressed communities. In F.M. Cox, J. L. Erlich, J. Rothman, \& J. E. Tropman (Eds.), Strategies of Community Organization (6th ed., pp. 65-100). Belmont, CA: Thomson Brooks/Cole.

Gautney, H. (2012). Occupy x: Repossession by occupation. South Atlantic Quarterly, 111(3), 597-607. doi: 10.1215/00382876-1596317

Goldbard, A. (2006). New creative community: The art of cultural development. Oakland, CA: New Village Press.

Goldberg, G. S. (2012). Economic inequality and economic crisis: A challenge for social workers. Social Work, 57(3), 211-225. doi: 10.1093/sw/sws005

Guba, E. G. (1990). The paradigm dialog. Newbury Park: Sage Publications.

Guilloud, S., \& Cordery, W. (2007). Fundraising is not a dirty word. In INCITE! Women of color against violence (Eds.), The revolution will not be funded: Beyond the non-profit industrial complex (pp. 79-123). Cambridge, MA: South End Press.

Gutierrez, L., \& Lewis, E. A. (1994). Community organizing with women of color: A feminist perspective. Journal of Community Practice, 1(2), 23-36. doi:10.1300/J125v01n0203

Habermas, J. (1984). The theory of communicative action, volume one: Reason and the rationalization of society. Boston: Beacon Press.

Hardcastle, D., Powers, P., \& Wencour, S. (2011). Community practice: Theories and skills for social workers. ( $3^{\text {rd }}$ ed.). NY: Oxford University Press.

Hardina, D. (2004). Guidelines for ethical practice in community organization. Social Work, 49(4), 595-604. doi: 10.1093/sw/49.4.595

Harper, C. L., \& Leicht, K. T. (2010). Exploring social change: America and the World (6th ed.). Upper Saddle River, NJ: Prentice Hall.

Hasenfeld, Y., \& Garrow, E. (2012). Nonprofit human-service organizations, social rights, and advocacy in a neoliberal welfare state. Social Service Review, 86(2), 295-322. doi: $10.1086 / 666391$ 
Healy, L. (2008). Exploring the history of social work as a human rights profession. International Social Work, 51(6), 735-748. doi: 10.1177/0020872808095247

Horton, M. (1998). The long haul: An autobiography. New York: Teachers College Press.

International Federation of Social Workers. (2005). Ethics in social work statement of ethics and principles. Retrieved May 8, 2011, from http://www.ifsw.org/f38000032.html

Johnson, A. (2006). Privilege, power, and difference. In A. Johnson, Privilege, power, and difference (pp. 12-28). Boston, MA: McGraw-Hill.

Kascak, O., \& Pupala, B. (2011). Governmentality - neoliberalism - education: The risk perspective. Journal of Pedagogy, 2(2), 145-158. doi: 10.2478/v10159-011-0007-z

Kivel, P. (2007). Social service or social change? In INCITE! Women of Color Against Violence (Ed.), The revolution will not be funded: Beyond the non-profit industrial complex (pp. 129-149). Cambridge, MA: South End Press.

Lange, E. A. (2004). Transformative and restorative learning: A vital dialectic for sustainable societies. Adult Education Quarterly, 54(2), 121-139. doi:10.1177/0741713603260276

Layde, P. M., Christiansen, A. L., Peterson, D. J., Guse, C. E., Maurana, C. A., \& Brandenburg, T. (2012). A model to translate evidence-based interventions into community practice. American Journal of Public Health, 102(4), 647-626. doi:10.2105/AJPH.2011.300468

Lee, J. A. (2001). The empowerment approach to social work practice: Building the beloved community (2nd ed.). New York: Columbia University Press.

Lethabo-King, T., \& Osayande, E. (2007). The filth on philanthropy: Progressive philanthropy's agenda to misdirect social justice movements. In INCITE! Women of Color Against Violence (Ed.), The revolution will not be funded: Beyond the non-profit industrial complex (pp. 79-90). Cambridge, MA: South End Press.

Levine, D. P. (2004). The birth of the citizenship schools: Entwining the struggles for literacy and freedom. History of Education Quarterly, 44(3), 388-414. Retrieved from http://www.jstor.org/stable/3218028

Lundy, C. (2011). Social work, social justice, and human rights: A structural approach to practice (2nd ed.). Toronto: University of Toronto Press.

Lyons, K. (2006). Globalization and social work: International and local implications. British Journal of Social Work, 36(1), 365-380. doi:10.1093/bjsw/bcl007

Marcuse, H. (1969). An essay on liberation. Boston: Beacon.

Margolin, L. (1997). Under the cover of kindness: The invention of social work. Charlottesville, VA: University of Virginia.

Marx, K., \& Engels, F. (1967). The communist manifesto (S. Moore, Trans.). New York: Penguin. 
Midgley, J. (2001). The United States: Welfare, work, and development. International Journal of Social Welfare, 10(4), 284-293. doi:10.1111/1468-2397.00185

Miller, M. (2010). Alinsky for the left: The politics of community organizing. Dissent, 57(1), 4351. doi:10.1353/dss. 0.0106

Morris, A. D. (1984). The origins of the civil rights movement: Black communities organizing for change. New York: The Free Press.

Mullaly, B. (2001). Confronting the politics of despair: Toward the reconstruction of progressive social work in a global economy and postmodern age. Social Work Education, 20(3), 303-320. doi: 10.1080/02615470120057406

Mullaly, B. (2007). The social work vision: A progressive view. In B. Mullaly, The new structural social work (pp. 44-69). Canada: Oxford Press.

National Association of Social Workers. (2008). NASW Code of Ethics. Retrieved March 9, 2013, from NASW: http://www.socialworkers.org/pubs/code/code.asp

Netting, F. E., Kettner, P. M., \& McMurtry, S. (2008). Social work macro practice (4th ed.). Boston: Allyn \& Bacon.

Nussbaum, M. C. (2003). Capabilities as fundamental entitlements: Sen and social justice. Feminist Economics, 9(2-3), 33-59.

Payne, C. M. (1995). I've got the light of freedom: The organizing tradition and the Mississippi freedom struggle. London: University of California Press.

Payne, M. (2005). Modern social work theory (3rd ed.). Chicago: Lyceum Books.

Piven, F. F. (2006). Challenging authority: How ordinary people change America. Lanham, MD: Rowman \& Littlefield Inc.

Piven, F. F., and Cloward, R. A. (1971). Regulating the poor: The functions of public welfare. New York: Pantheon.

Pyles, L. (2009). Progressive community organizing: A critical approach for a globalizing world. New York: Routledge.

Pyles, L. (2010). Global justice in the time of Obama: A call to organize. Social Work, 55(1), 9092. doi: http://dx.doi.org.proxy.library.vcu.edu/10.1093/sw/55.1.90

Reisch, M. (2011). Being a radical social worker in reactionary times: Keynote address to the $25^{\text {th }}$ Annual Social Welfare Action Alliance (pp.1-22). Washington D.C.: Social Welfare Action Alliance.

Reisch, M. (2005). Radical community organizing. In M. Weil (Ed.), The handbook of community practice (pp. 287-304). Thousand Oaks, CA: Sage Publications.

Ritzer, G. (2008). Modern sociological theory (7th ed.). New York: McGraw-Hill. 
Rothman, J. (2007). Multi modes of intervention at the macro level. Journal of Community Practice, 15(4), 11-40. doi: 10.1300/J125v15n04

Rothman, J., Erlich, J. L., \& Tropman, J. E. (Eds.). (2001). Strategies of community intervention (6th ed.). Belmont, CA: Wadsworth/Thomson Learning.

Rubin, A., \& Babbie, E. (2011). Research methods for social work (3rd ed.). Upper Saddle River, NJ: Brooks and Cole.

Slaughter, S., \& Silva, E. (1980). Looking backwards: How foundations formulated ideology in the progressive period. In R. Arnove (Ed.), Philanthropy and cultural imperialism (pp. 55-86). Boston: GK Hall.

Smith, J.A. (1999). The evolving role of American foundations. In Charles Clotfelter and Thomas Erlich (Eds.), Philanthropy and the non-profit sector in a changing America (pp. 34-51). Bloomington, IL: University of Indiana Press: 34-51.

Smith, A. (2007). Introduction: The revolution will not be funded. In INCITE Women of Color Against Violence (Ed.), The revolution will not be funded: Beyond the non-profit industrial complex (pp. 1-18). Cambridge, MA: South End Press.

Snow, D. (2004). Social movements as challenges to authority: Resistance to an emerging conceptual hegemony. In D. J. Meyers \& D. M. Cress (Eds.), Authority in contention: Research in social movements, conflicts, and change (pp. 3-25). Cambridge, MA: Emerald.

Solomon, B. (1976). Black empowerment: Social work in oppressed communities. New York: Columbia University Press.

Soss, J., Fording, R., \& Schram, S. (2011). Disciplining the poor: Neoliberal paternalism and the persistent power of race. Chicago: University of Chicago.

Suspitsyna. (2012). Higher education for economic advancement and engaged citizenship: An analysis of the U.S. Department of Education discourse. Journal of Higher Education, 83(1), 49-72. doi: 10.1353/jhe.2012.0003

Tervalon, M., \& Murray-Garcia, J. (1998). Cultural humility verses cultural competence: A critical distinction in defining physician training outcomes in multicultural education. Journal of Healthcare for the Poor and Underserved, 9(2), 117-126.

Thomas, M. L., O'Connor, M. K., \& Netting, F. E., (2011). A framework for teaching community practice. Journal of Social Work Education, 47(2), 337-355. doi:10.5175/JSWE.2011.200900081

Tilly, C. (1978). From mobilization to revolution. New York: McGraw-Hill.

Wagner, D. (1990). The quest for a radical profession: Social service careers and political ideology. Lantham, MD: University Press of America.

Wood, A. M. (2004). Karl Marx. New York: Routledge. 